\title{
Analysis of the operating parameters in a Stirling cryocooler
}

\author{
Diego José Maldonado Aguilar ${ }^{1, *}$ Juan Antonio Auñón Hidalgo ${ }^{1}$ Mauri Eskubi ${ }^{2}$ and \\ Pablo Martínez ${ }^{2}$ \\ ${ }^{1}$ Department of Mechanical Engineering, Thermal Engineering and Fluid Mechanics, University of \\ Málaga (UMA), 29071 Málaga, Spain \\ ${ }^{2}$ CS Centro Stirling S. Coop, Avda. Álava,3, Aretxabaleta (Gipuzcoa), 20550 Spain
}

\begin{abstract}
In this work, the results obtained in different tests performed on a Stirling cryocooler are shows, as well as a comparative analysis of these results with different load pressures. The prototype is a single-acting Stirling engine with a piston and displacer, which is used to liquefy air with helium as the working fluid; this is an integral Stirling ( $\beta$-type). A three-phase asynchronous electric motor drives the Stirling engine and cooling, in the hot focus, is performed with a pressurized water circuit. In the cold focus are reached very low temperatures, around $75 \mathrm{~K}\left(-198{ }^{\circ} \mathrm{C}\right)$. The study has been developed at different load pressures of the working fluid and it shows a comparative analysis about the most important work parameters evolution. The parameters studied are the following: cooling water inlet and outlet temperatures, cold and hot focus temperatures, voltage and intensity consumed by the electric motor that drives the Stirling engine and quantity of liquid air obtained. The results show that it is very likely to use this configuration in industrial processes when they need cold and heat simultaneously.
\end{abstract}

\section{Introduction}

Stirling engines can be classified into three main groups ( $\alpha$-type, $\beta$-type and $\gamma$-type), depending on the position of the piston and the displacer [1]. The first Stirling engine cooler was manufactured by Alexander Kirk in 1874 [2].

This paper studies a Stirling cryocooler, which follows an inverse Stirling cycle. The Stirling cryocooler does not use valves to control the flow of the working fluid, it has a regenerative heat exchanger, the compression is done mechanically and it is a single-acting machine equipped with a piston and displacer. This type of motors is called an integral Stirling engine, according to the Walker classification that can be seen in Fig. $1[3,8]$.

\footnotetext{
${ }^{*}$ Corresponding author: djmaldonado@uma.es
} 


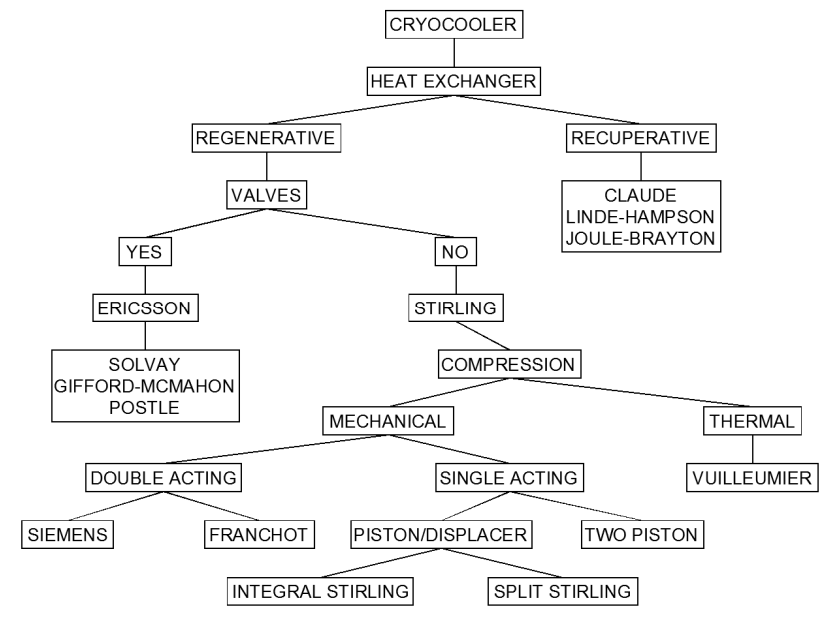

Fig. 1. Classification of cryocoolers.

As stated before, the Stirling cryocooler follows an inverse Stirling cycle. The cycle is composed of four heat transfer processes, two isothermal processes and two isochoric processes. The Temperature-Entropy $(\mathrm{T}-\mathrm{S})$ and Pressure-Volume $(\mathrm{P}-\mathrm{V})$ diagrams are shown in Fig. 2, where we can see the absorbed heat $\left(\mathrm{Q}_{\mathrm{abs}}\right)$ and the transmitted heat $\left(\mathrm{Q}_{\text {tra }}\right)$ in the cycle.
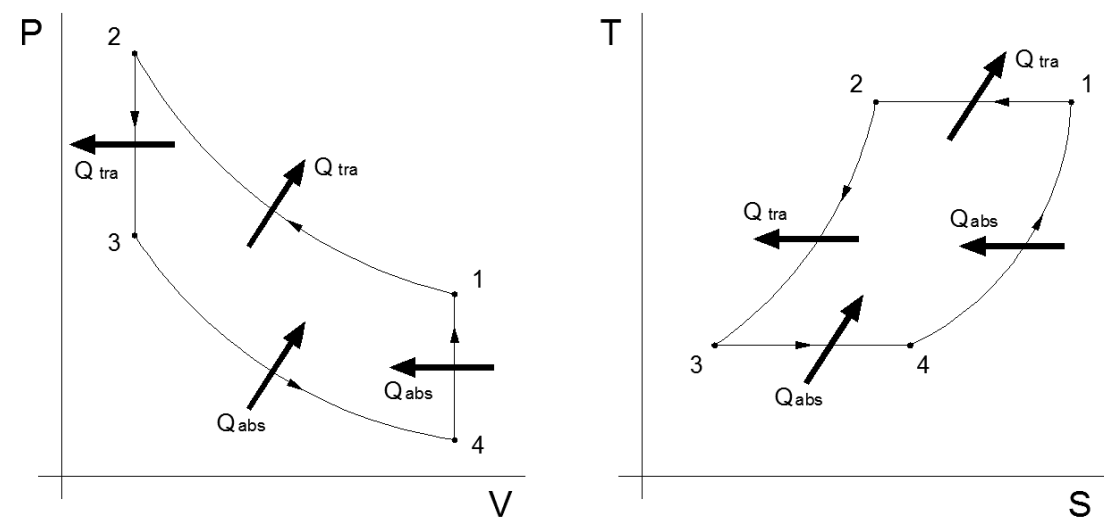

Fig. 2. P-V and T-S diagrams.

The different processes are as follows [3-7,9-12]:

- Process 1-2: Isothermal compression in the compression space. The heat is transferred from the working fluid to the external sink.

- Process 2-3: Constant volume regenerative cooling. The heat is transferred from the working fluid to the regenerative matrix. The reduction in temperature at constant volume causes a reduction in pressure.

- Process 3-4: Isothermal expansion in the expansion space. The heat is absorbed for the working fluid from an external source.

- Process 4-1: Constant volume regenerative heating. The heat is absorbed for the working fluid from the regenerative matrix. 
Fig. 3 shows a section of the Stirling cryocooler where the primary parts are indicated $[13,14]$.

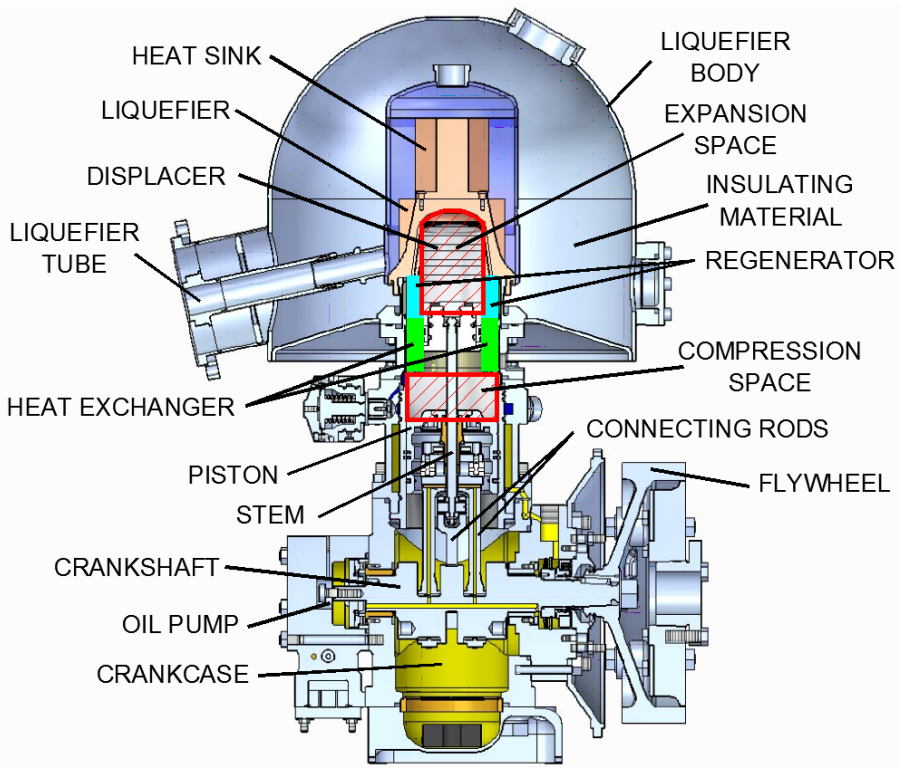

Fig. 3. Primary parts in the Stirling cryocooler.

There are many fields where cryogenic refrigeration can be used (civil, military, medical, industrial and scientific). The applications are as follows: infrared detectors, medical instrumentation (scanner, magnetic resonance imaging, cryosurgery, positron emission tomography, cryopreservation of biological material and superconducting quantum interference devices SQUIDs), cryopumping, electronics (semiconductor and superconductor), cryobiology, scientific research and industrial and commercial applications (food preservation, metallurgical process, liquefaction and gas separation) $[9,15]$.

In the current situation in which the world finds itself, due to the pandemic caused by the SARS-CoV-2 virus that produces the COVID-19 disease, it is essential to seek advances in the preservation applications of biological material. Recently, the Junta de Andalucía has created a Biobank for the collection, processing and storage of biological samples from patients who have been infected by SARS-CoV-2 at any stage of their clinical evolution. The optimum storage temperature in order to preserve these samples is $193 \mathrm{~K}\left(-80^{\circ} \mathrm{C}\right)$ and therefore the Stirling cryocooler could be used for this purpose. This Biobank will be useful for numerous biomedical research projects that contribute to the design of a treatment or effective vaccine against the coronavirus.

\section{Facilities description}

The installation to obtain liquid air is located in the Laboratory of Thermal Engines and Machines of the University of Málaga (Fig. 4). A diagram of this installation is shown in Fig. 5. 


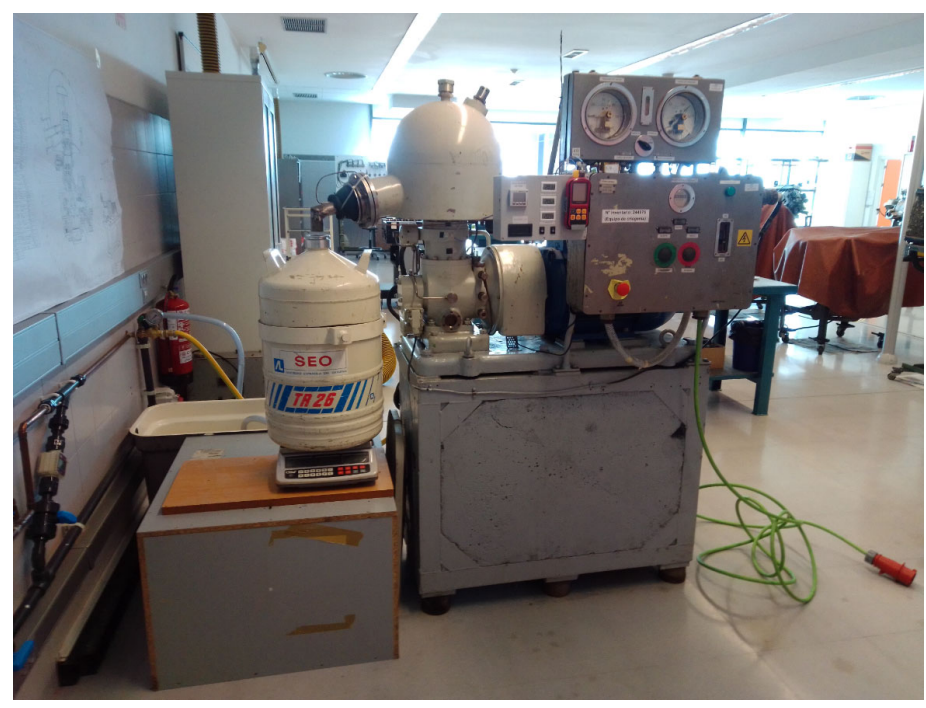

Fig. 4. Cryogenic facility.

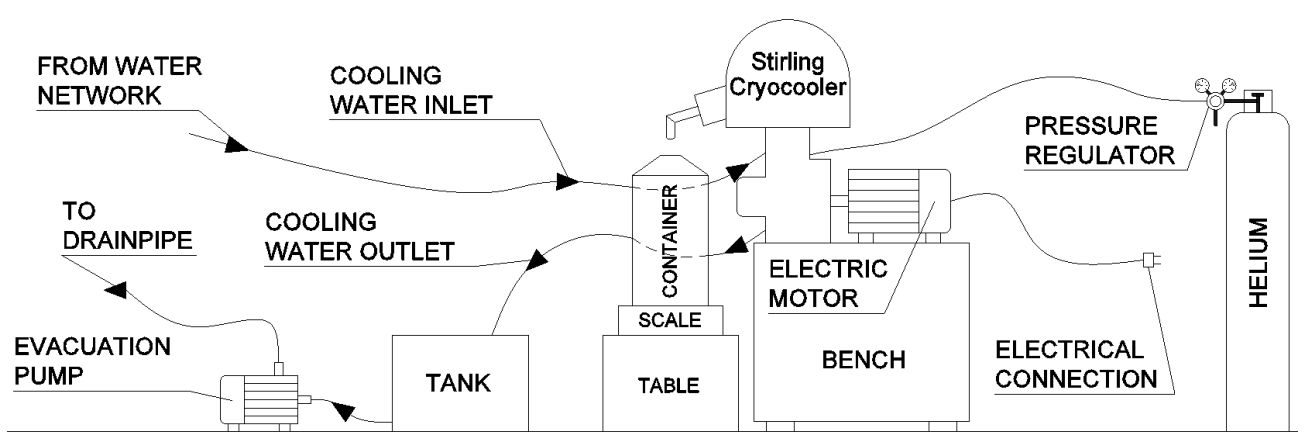

Fig. 5. Cryogenic facility scheme.

The installation has the following components:

- Stirling cryocooler: The prototype is a $\beta$-type Stirling engine that is powered by an electric motor. Table 1 shows the basic specifications and operating conditions of the Stirling cryocooler as well as geometrical and physical parameters.

- Cooling installation (Fig. 6): This system consists of a pressurized water inlet network, an evacuation network and shut-off valves to regulate the inlet flow to the Stirling cryocooler. The cooling water outlet of Stirling cryocooler discharges directly into an auxiliary tank and by means of an electric pump the water is evacuated to drainpipe.

- Installation of helium: It consists of a pressurized helium bottle and a series of pipes and connections to be able to introduce helium inside the Stirling cryocooler.

- Bench: It is a reinforced concrete base on which the Stirling cryocooler and the electric motor are fixed.

- Container: The liquid air obtained is collected in a container suitable for cryogenic storage.

- Scale: The container is placed on the scale and thus the amount of liquid air generated can be measured in real time. 
Table 1. The basic specifications, operating conditions, geometrical and physical parameters of the Stirling cryocooler.

\begin{tabular}{lclc}
\hline Machine type & $\begin{array}{c}\text { Single-acting Stirling engine with a piston and } \\
\text { displacer, also known as integral Stirling } \\
\text { crank-slider drive }\end{array}$ & Piston diameter (mm) & 101.6 \\
Driving mechanism & Helium & Piston length (mm) & 92 \\
Working fluid & 19 & Piston stroke (mm) & 52 \\
Standard load pressure (bar) & 24 & Piston swept volume (mm $\left.)^{3}\right)$ & 421580.6 \\
Standard work pressure (bar) & Pressurized water & Piston material & Cast iron \\
Cooling system & 1000 & Displacer diameter (mm) & 70 \\
Flow of cooling water $\left(\mathrm{l} \mathrm{h}^{-1}\right)$ & Combination splash and force feed & Displacer length (mm) & 113 \\
Lubrication system & Turbocharger oil & Displacer stroke (mm) & 30 \\
Oil lubrication & Three-phase asynchronous motor & Displacer swept volume (mm $\left.{ }^{3}\right)$ & 115453.5 \\
Electric motor & 18.5 & Displacer material & Stainless steel \\
Rated power of electric motor $(\mathrm{kW})$ & 1460 & Regenerator material & copper and zinc \\
Rotate speed $(\mathrm{rpm})$ & 380 & Expansion dead volume $\left(\mathrm{mm}^{3}\right)$ & 13163.9 \\
Line voltage $(\mathrm{V})$ & 50 & Compression dead volume $\left(\mathrm{mm}^{3}\right)$ & 29505.6 \\
Frequency $(\mathrm{Hz})$ & & Phase angle $($ degree $)$ & 110 \\
\hline
\end{tabular}

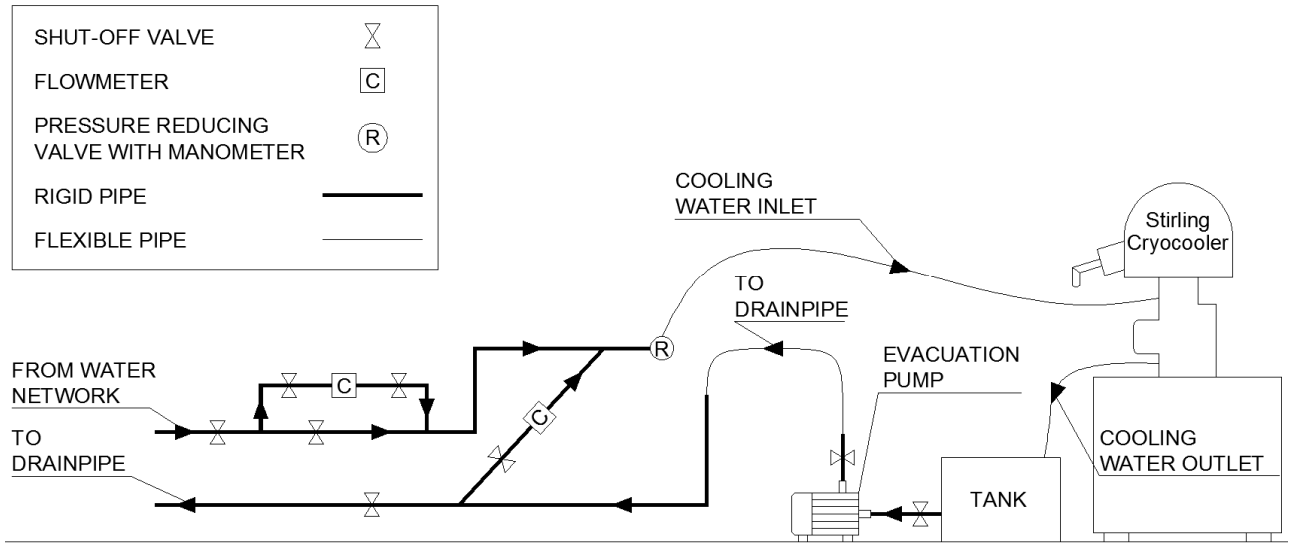

Fig. 6. Cooling facility scheme.

- Control and measurement main panel: This panel is divided into three parts. On one side is the control box (Fig. 7). In this box there are several light indicators that warn us in case of a problem in the oil, cooling or helium circuits and an emergency stop button for safety.

Just above this box there is another one where you can see the helium pressure and the pressure of the refrigeration circuit. 


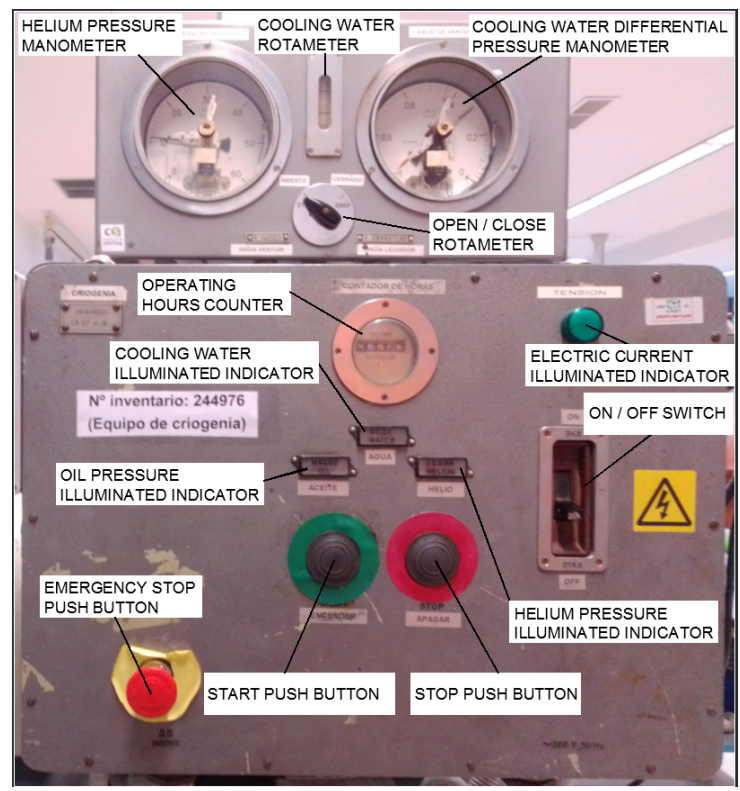

Fig. 7. Control panel.

Finally, there is a measurement box (Fig. 8). Different parameters are displayed in this box: cooling water inlet and outlet temperatures and flows, hot and cold focus temperatures, ambient temperature, voltage and intensity consumed by the electric motor and speed of the electric motor.

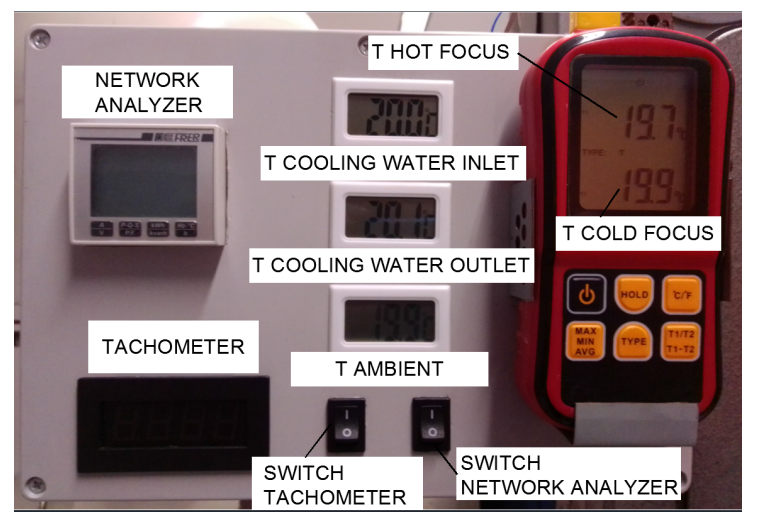

Fig. 8. Measurement panel.

\section{Carrying out the tests}

The manufacturer of the Stirling cryocooler recommends a standard load pressure of the working fluid of 19 bar with the engine stopped. Nevertheless, different tests are carried out at the following load pressures: 14 to 20 bar.

When the Stirling cryocooler is started, the helium pressure increases about 5 bar. This pressure is called work pressure. 
The following parameters are recorded:

- Hot focus temperature: Measurements are made at the points T1, T2, T3, T4 and T5 (Fig.

9).

- Cold focus temperature: This temperature is measured at point T6 (Fig. 9).

- Cooling water inlet and outlet temperatures.

- Ambient temperature.

- Cooling water flow.

- Motor speed.

- Voltage, intensity, power and power factor.

- Amount of liquid air.
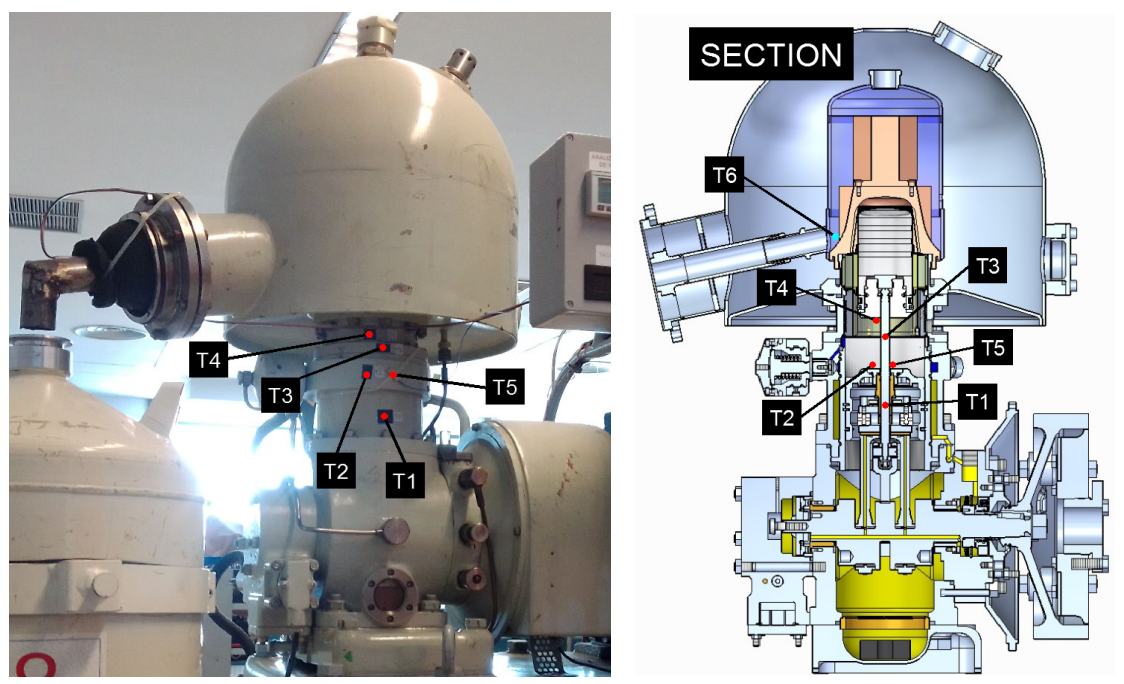

Fig. 9. Temperature measurement points at the cold and hot focus.

\section{Experimental results, study of the operating parameters and discussion}

The experimental results obtained in different tests are shown below. Several graphs are presented showing the evolution over time of some machine parameters at different load pressures of the working fluid and an analysis of each graph is performed.

Fig. 10 shows the variation of the hot focus temperature throughout the test for different load pressures of helium and Fig. 11 shows the variation of the cold focus temperature. The hot focus temperature is measured at point $\mathrm{T} 5$ and the cold focus temperature at point $\mathrm{T} 6$ (Fig. 9). 


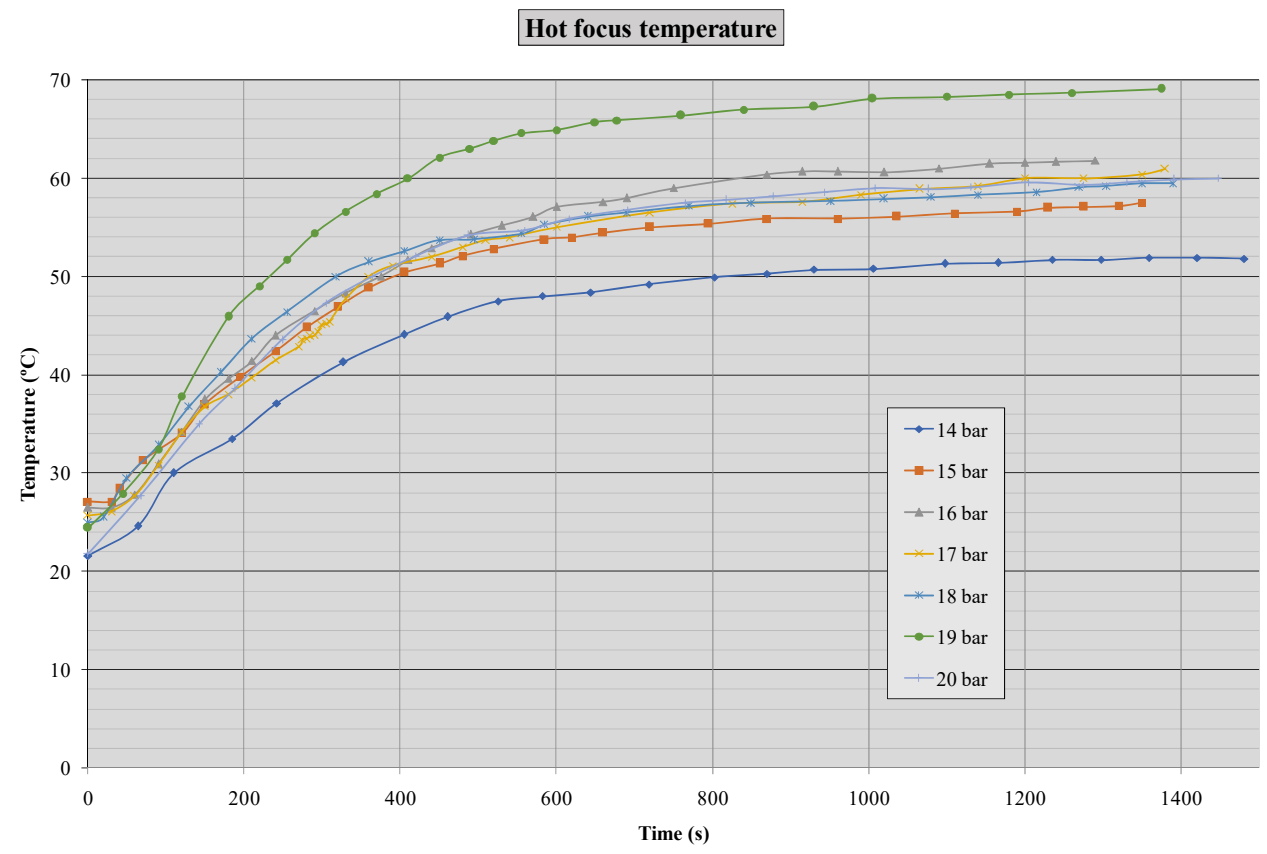

Fig. 10. Variation of the hot focus temperature.

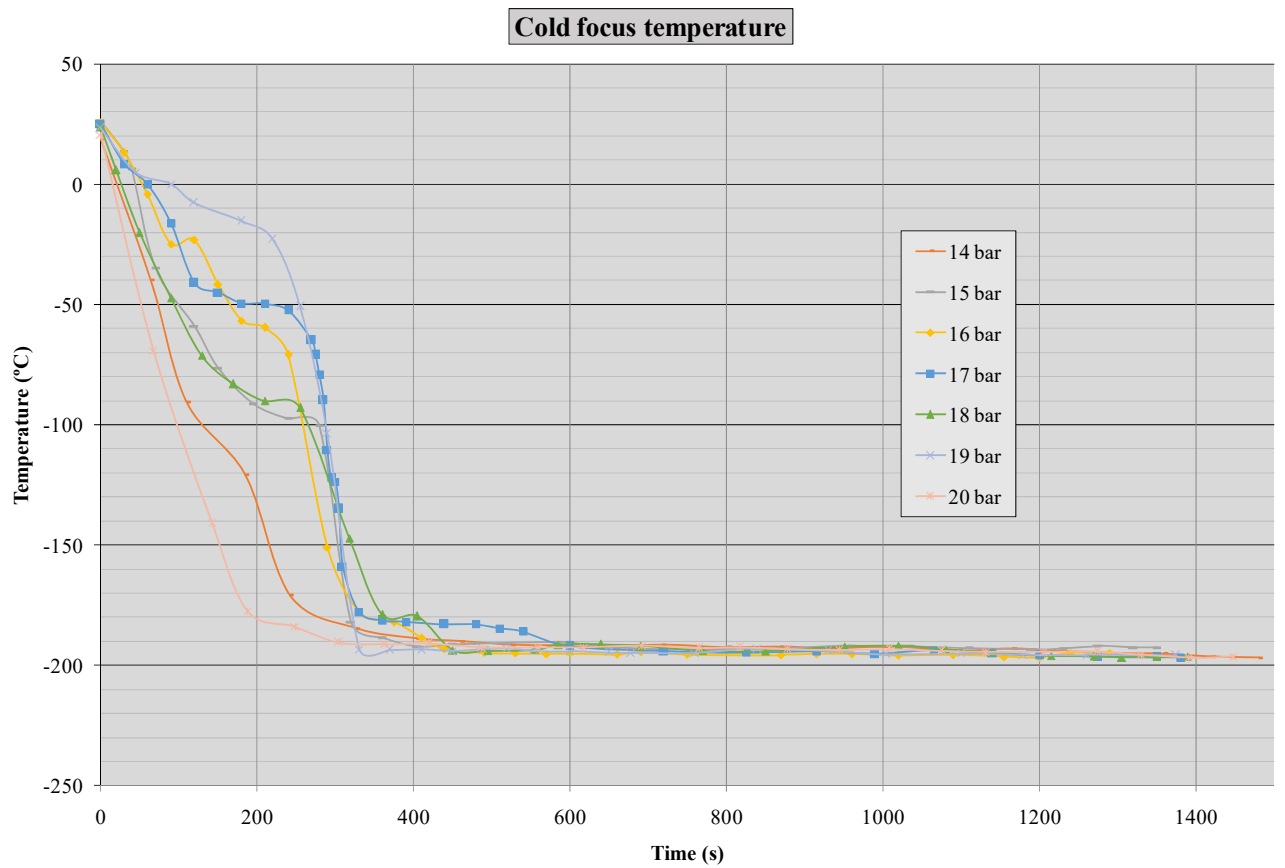

Fig. 11. Variation of the cold focus temperature.

As it is showed in Fig. 10, at first there is a rapid rise in temperature, to then stabilize around a maximum value for each test. This maximum value occurs for 19 bar $\left(69.1{ }^{\circ} \mathrm{C}\right)$. 
In the cold focus, in the first 300 seconds, there is a rapid decrease in temperature. After 600 seconds it stabilizes around $-198^{\circ} \mathrm{C}$.

The evolution of liquid air mass flow obtained for each test is represented in Fig. 12.

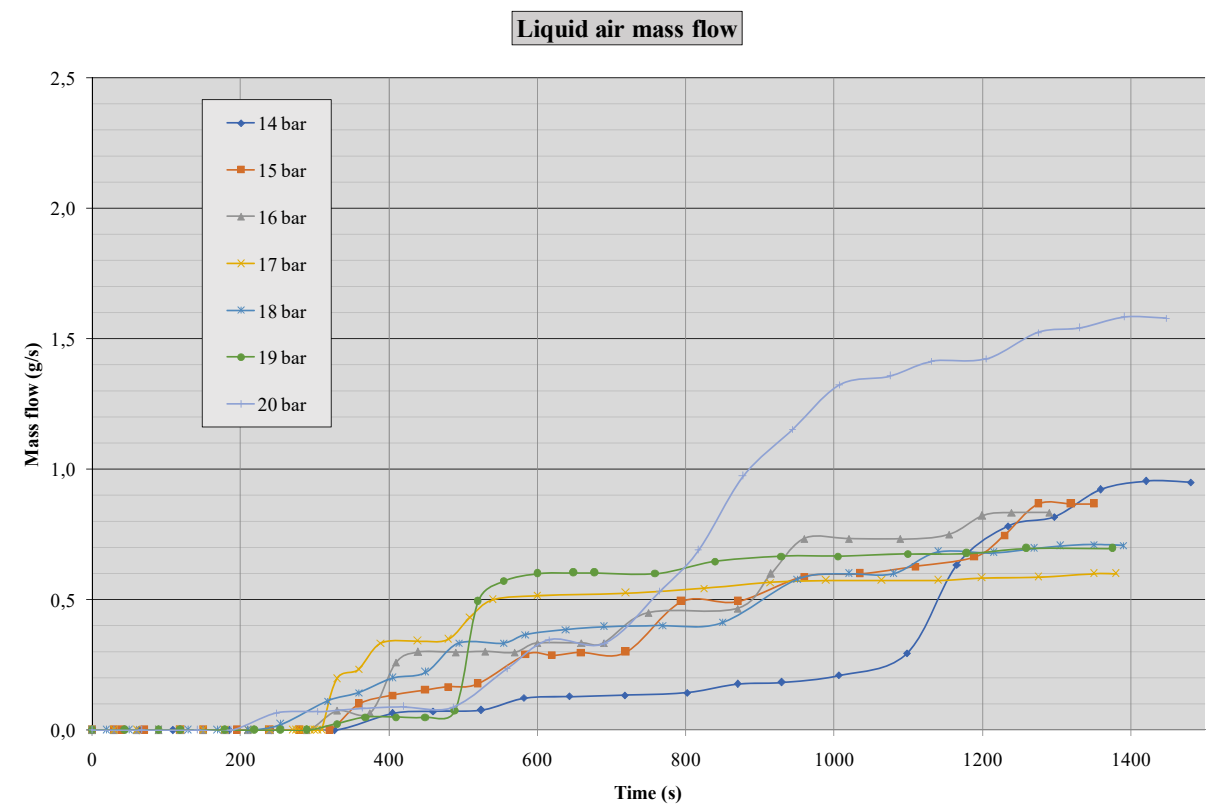

Fig. 12. Evolution of liquid air mass flow obtained.

Finally, Fig. 13 shows the electric power consumed by the electric motor that drives the Stirling cryocooler.

Power consumed by the electric motor

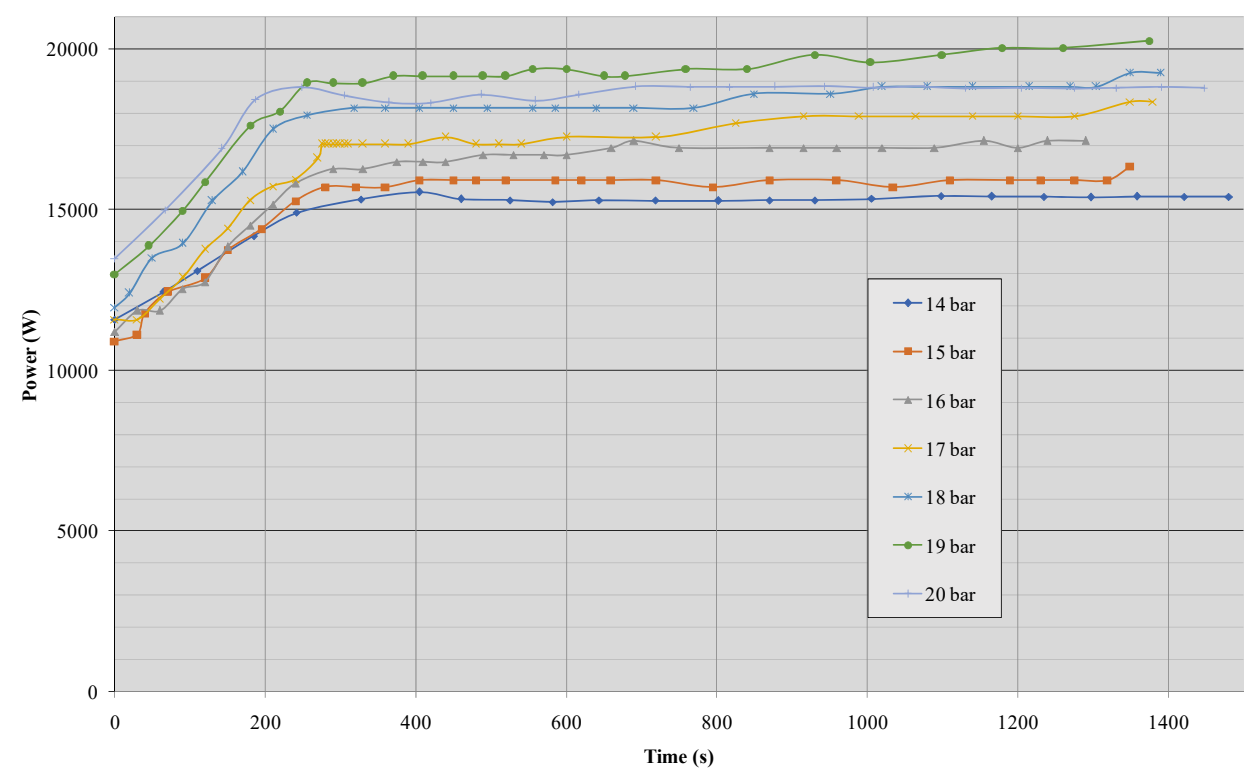

Fig. 13. Power consumed by the electric motor. 
The power consumed by the electric motor $\left(P_{\text {ele }}\right)$ is calculated using the equation $(1)$ :

$P_{\text {ele }}=\sqrt{3} \cdot V \cdot I \cdot \cos \varphi$

where $\mathrm{V}$ is the line voltage, $\mathrm{I}$ is the line current and $\cos \varphi$ is the power factor.

As can be seen in Fig. 13, the power consumed by the electric motor increases rapidly from motor is started up to approximately 300 seconds. After 300 seconds, it begins to generate liquefied air and there is a slight rise of the power consumed.

Table 2 shows the maximum powers that have been obtained, the maximum values reached in the hot focus for each test and the values of liquid air mass flow obtained for each test in permanent regime.

Table 2. Maximum powers consumed by the electric motor, maximum temperature reached in the hot focus and liquid air mass flow obtained in permanent regime.

\begin{tabular}{cccccccc}
\hline Test & $\mathbf{1 4} \mathbf{~ b a r}$ & $\mathbf{1 5} \mathbf{~ b a r}$ & $\mathbf{1 6} \mathbf{~ b a r}$ & $\mathbf{1 7} \mathbf{b a r}$ & $\mathbf{1 8 ~ b a r}$ & $\mathbf{1 9} \mathbf{b a r}$ & $\mathbf{2 0 ~ b a r}$ \\
\hline $\begin{array}{c}\text { Max. power } \\
\text { consumed }\end{array}$ & $15396 \mathrm{~W}$ & $16352 \mathrm{~W}$ & $17138 \mathrm{~W}$ & $18346 \mathrm{~W}$ & $19263 \mathrm{~W}$ & $20249 \mathrm{~W}$ & $18782 \mathrm{~W}$ \\
$\begin{array}{c}\text { Max. temp. } \\
\text { reached }\end{array}$ & $51.8^{\circ} \mathrm{C}$ & $57.5^{\circ} \mathrm{C}$ & $61.8^{\circ} \mathrm{C}$ & $61{ }^{\circ} \mathrm{C}$ & $59.5^{\circ} \mathrm{C}$ & $69.1{ }^{\circ} \mathrm{C}$ & $60^{\circ} \mathrm{C}$ \\
$\begin{array}{c}\text { Liquid air } \\
\text { mass flow }\end{array}$ & $0.95 \mathrm{~g} \mathrm{~s}-1$ & $0.87 \mathrm{~g} \mathrm{~s}-1$ & $0.83 \mathrm{~g} \mathrm{~s}-1$ & $0.60 \mathrm{~g} \mathrm{~s}-1$ & $0.71 \mathrm{~g} \mathrm{~s}-1$ & $0.70 \mathrm{~g} \mathrm{~s}-1$ & $1.58 \mathrm{~g} \mathrm{~s}-1$ \\
\hline
\end{tabular}

Next, the energy consumed, transmitted and extracted in the installation is calculated for the different load pressures of helium:

$E_{\text {ele }}=P_{\text {ele }} \cdot t_{e}$

$E_{r e f}=m_{r e f} \cdot C_{p} \cdot \Delta T$

$E_{N_{2}}=m_{N_{2}} \cdot C_{p N_{2}} \cdot \Delta T_{N_{2}}$

$E_{O_{2}}=m_{O_{2}} \cdot C_{p O_{2}} \cdot \Delta T_{O_{2}}$

$E_{E N_{2}}=m_{N_{2}} \cdot L_{V N_{2}}$

$E_{E_{2}}=m_{O_{2}} \cdot L_{V O_{2}}$

where $E_{\text {ele }}$ is the energy consumed by the electric motor, $E_{r e f}$ is the energy transmitted to the cooling water, $E_{N 2}$ is the energy extracted from the nitrogen to lower its temperature, $E_{\mathrm{O} 2}$ is the energy extracted from the oxygen to lower its temperature, $E_{E N 2}$ is the energy extracted from the nitrogen for the change of state and $E_{E O 2}$ is the energy extracted from the oxygen for the change of state.

The total energy extracted from air to liquefy it is calculated separately as the energy extracted from nitrogen and the energy extracted from oxygen. On the one hand, the energy required to lower the temperature of oxygen and nitrogen has been calculated, from the 
ambient temperature to the liquefaction temperature, and on the other hand, the energy required for the change of state (from gaseous to liquid state). Therefore, the total energy extracted from the air to liquefy it $\left(E_{\text {air }}\right)$ is calculated with the following equation:

$$
E_{\text {air }}=E_{N_{2}}+E_{\mathrm{O}_{2}}+E_{E N_{2}}+E_{E O_{2}}
$$

Table 3 shows the results obtained.

Table 3. Energy consumed, transmitted and extracted.

\begin{tabular}{|c|c|c|c|c|c|c|c|}
\hline Test & $\begin{array}{c}\text { Energy } \\
\text { consumed } \\
\text { by the } \\
\text { electric } \\
\text { motor }\left(E_{\text {ele }}\right) \\
{[\mathrm{kJ}]}\end{array}$ & $\begin{array}{c}\text { Energy } \\
\text { transmitted } \\
\text { to the } \\
\text { cooling } \\
\text { water }\left(E_{r e f}\right) \\
{[\mathrm{kJ}]}\end{array}$ & $\begin{array}{c}\text { Energy } \\
\text { extracted } \\
\text { from } \mathrm{N}_{2} \text { to } \\
\text { decrease its } \\
\text { temp. }\left(E_{N 2}\right) \\
{[\mathrm{kJ}]}\end{array}$ & $\begin{array}{c}\text { Energy } \\
\text { extracted } \\
\text { from } \mathrm{O}_{2} \text { to } \\
\text { decrease its } \\
\text { temp. }\left(E_{O 2}\right) \\
{[\mathrm{kJ}]}\end{array}$ & $\begin{array}{c}\text { Energy } \\
\text { extracted } \\
\text { from } \mathrm{N}_{2} \text { to } \\
\text { change its } \\
\text { state }\left(E_{E N 2}\right) \\
{[\mathrm{kJ}]}\end{array}$ & $\begin{array}{c}\text { Energy } \\
\text { extracted } \\
\text { from } \mathrm{O}_{2} \text { to } \\
\text { change its } \\
\text { state }\left(E_{E O 2}\right) \\
{[\mathrm{kJ}]}\end{array}$ & $\begin{array}{c}\text { Total } \\
\text { energy } \\
\text { extracted } \\
\text { from the air } \\
\left(E_{\text {air }}\right) \\
{[\mathrm{kJ}]}\end{array}$ \\
\hline 14 bar & 22048.59 & 17771.65 & -77.24 & -17.48 & -68.46 & -20.06 & -183.23 \\
\hline 15 bar & 20298.68 & 15951.26 & -89.92 & -20.39 & -77.21 & -22.62 & -210.14 \\
\hline 16 bar & 20303.69 & 16282.57 & -91.50 & -20.75 & -78.46 & -22.99 & -213.70 \\
\hline 17 bar & 22696.50 & 19054.46 & -100.71 & -22.83 & -86.43 & -25.32 & -235.30 \\
\hline 18 bar & 24262.92 & 20016.48 & -97.17 & -22.03 & -83.77 & -24.55 & -227.52 \\
\hline 19 bar & 25443.80 & 20844.77 & -106.45 & -24.14 & -91.28 & -26.74 & -248.61 \\
\hline 20 bar & 26411.08 & 23803.51 & -183.73 & -41.59 & -161.61 & -47.35 & -434.29 \\
\hline
\end{tabular}

As can be seen in the table above, the negative sign indicates that it is an energy extracted.

The coefficients of performance (COP) and losses are calculated with the following equations:

$$
\begin{aligned}
& C O P_{\text {ref }}=\frac{E_{\text {ref }}}{E_{\text {ele }}} \\
& C O P_{\text {lic }}=\left(E_{\mathrm{N}_{2}}+E_{\mathrm{O}_{2}}+E_{E N_{2}}+E_{E O_{2}}\right) / E_{\text {ele }} \\
& L=100 \%-\left(C O P_{\text {ref }}+C O P_{\text {lic }}\right)
\end{aligned}
$$

where $C O P_{\text {ref }}$ is the coefficient of performance in the refrigeration circuit, $C O P_{\text {lic }}$ is the coefficient of performance in the liquefied air and L is the loss in the cryogenic facility.

Table 4 shows the COP and losses that occur in the cryogenic facility. 
Table 4. COP and losses in the cryogenic facility.

\begin{tabular}{|c|c|c|c|}
\hline Test & $\begin{array}{l}\text { Coefficient of } \\
\text { performance in the } \\
\text { refrigeration circuit } \\
\quad\left(C O P_{r e f}\right)[\%]\end{array}$ & $\begin{array}{c}\text { Coefficient of } \\
\text { performance in the } \\
\text { liquefied air }\left(C O P_{l i c}\right) \\
{[\%]}\end{array}$ & $\operatorname{Loss}(\mathrm{L})[\%]$ \\
\hline 14 bar & 80.60 & 0.83 & 18.57 \\
\hline 15 bar & 78.58 & 1.04 & 20.38 \\
\hline 16 bar & 80.20 & 1.05 & 18.75 \\
\hline 17 bar & 83.95 & 1.04 & 15.01 \\
\hline 18 bar & 82.50 & 0.94 & 16.56 \\
\hline 19 bar & 81.92 & 0.98 & 17.10 \\
\hline 20 bar & 90.13 & 1.64 & 8.23 \\
\hline
\end{tabular}

The COP in the refrigeration circuit is calculated due to the possibility of taking advantage of the energy contained in the hot water for using it in other processes.

\section{Conclusions}

This paper shows the results obtained after the different tests carried out at the Stirling cryocooler. Based on the experimental results, the conclusions are summarized as follows: - An increase in the load pressure of the working fluid result in an increase in the intensity consumed by the electric motor that drives the Stirling cryocooler, and therefore a direct increase in the energy consumption in the test, with the exception of the test at 20 bar.

- The cold focus temperature is not affected by the load pressure of the working fluid. This temperature stabilizes around $75 \mathrm{~K}\left(-198^{\circ} \mathrm{C}\right)$, ideal temperature to liquefy the air.

- During the tests an increase in the helium pressure is observed. This increase is about 5 bar for all load pressures of helium and therefore the pressures during the tests range from 19 bar to 25 bar, which is called work pressure.

- The engine speed does not change during the tests and remains constant at $1460 \mathrm{rpm}$.

- The cooling water outlet temperature is suitable for use in many industrial processes where a water flow between $50^{\circ} \mathrm{C}$ and $70^{\circ} \mathrm{C}$ is required.

- The test at 20 bar is the one that reports the highest coefficient of performance in the refrigeration circuit and coefficient of performance in the liquefied air, without having the highest power consumption. Therefore the ideal operating pressure for Stirling cryocooler is at 20 bar.

On the whole, the results show that it is very likely to use this configuration in industrial processes when they need heat and cold simultaneously. By means of the control of the cooling flow in the hot focus it would be possible to reach a temperature compatible with many industrial processes.

This study was prepared by using the infrastructure of the Area of Thermal Machines and Motors, belonging to the Department of Mechanical, Thermal and Fluids Engineering of the University of Málaga (UMA). 


\section{References}

1. B.G. Kim, W.S. Park, B.G. Koo, S.H. Park. J. Mech. Sci. Tech., 32 (9), 4473-4484 (2018).

2. A. Kirk. Proc. Inst. Civil Eng. 37, 244-315 (1874).

3. G. Walker. Cryocoolers. Part 1: Fundamentals. New York: Plenum Press (1983).

4. S. Alfarawi, R. AL-Dadah, S. Mahmoud. Ap. Ther. Engi., 106, 1380-1390 (2016).

5. C. Çınar, F. Aksoy, H. Solmaz, E. Yılmaz, A. Uyumaz. Ap. Ther. Engi., 130, 13731379 (2018).

6. J. Park, J. Ko, H. Kim, Y. Hong, H. Yeom, S. Park, S. In. Ap. Ther. Engi., 164, 114504 (2020).

7. D.J. Shendage, S.B. Kedare, S.L. Bapat. Ap. Ther. Engi., 124, 595-615 (2017).

8. G. Walker. Cryocoolers. Part 2: Applications. New York: Plenum Press (1983).

9. G. Walker, E.R. Bingham. Low-Capacity Cryogenic Refrigeration. New York: Oxford University Press (1994).

10. I. Barreno. Desarrollo de una metodología de cálculo para el diseño de una bomba de calor Stirling oscilante. Doctoral thesis (2015).

11. R. Li, L. Grosu. Int. J. Ref., 80, 92-105 (2017).

12. M.Z. Getie, F. Lanzetta, S. Bégot B.T. Admassu, A.A. Hassen. Int. J. Ref., 118, 173187 (2020).

13. I. Barreno, G. Fernández, E. Sangüesa. Criogenia con tecnología Stirling. Centro Stirling (2010).

14. G. Walker. Stirling Engines. New York: Oxford University Press (1980).

15. R. Radebaugh. J. Phy.: Cond. Mat., 21 (16), 164219 (2009).

16. Y. Xu, D. Sun, X. Qiao, Y.S.W. Yu, N. Zhang, J. Zhang, Y. Cai. Cryo., 83, 78-84 (2017).

17. K. Wang, S.R. Sanders, S. Dubey, F.H. Choo, F. Duan. Ren. Sust. Ener. Rev., 62, 89108 (2016). 